\title{
Commentary: Hybrid graft to the rescue of the bilateral internal thoracic artery debate-Is it time for new technology or new techniques?
}

\author{
Moritz C. Wyler von Ballmoos, MD, PhD, MPH, ${ }^{\mathrm{a}, \mathrm{b}}$ and G. Hossein Almassi, MD
}

\footnotetext{
From the a Department of Cardiothoracic Surgery, DeBakey Heart \& Vascular Center, Houston Methodist Hospital, Houston, Tex; ${ }^{b}$ Weill Cornell Medicine, New York, NY; and ${ }^{c}$ Division of Cardiothoracic Surgery, Department of Surgery, Medical College of Wisconsin, Milwaukee, Wis.

Disclosures: Authors have nothing to disclose with regard to commercial support.

Received for publication March 6, 2019; accepted for publication March 7, 2019; available ahead of print April $24,2019$.

Address for reprints: G. Hossein Almassi, MD, Division of Cardiothoracic Surgery, Medical College of Wisconsin, 8701 Watertown Plank Rd, Milwaukee, WI 53226 (E-mail: halmassi@mcw.edu).

J Thorac Cardiovasc Surg 2020;159:474-502

$0022-5223 / \$ 36.00$

Copyright (c) 2019 by The American Association for Thoracic Surgery https://doi.org/10.1016/j.jtcvs.2019.03.082
}

Since the first report of coronary artery bypass surgery (CABG) in the 1960s, the field of cardiac revascularization has come a long way. ${ }^{1,2}$ On average, this procedure is performed on 44 out of 100,000 people according to 2017 data from the Organisation for Economic Co-operation and Development. This number is twice as high in the United States, and even higher in some of the developing countries. ${ }^{3}$ CABG remains the mainstay for coronary revascularization, and it is currently the only procedure with a survival benefit outside acute coronary syndrome, where percutaneous coronary intervention has shown its greatest value. Autologous internal thoracic artery (ITA) grafts, radial artery grafts, and saphenous vein grafts are the most commonly used conduits for CABG. The improved coronary artery disease-related survival after CABG has been shown conclusively, however, only for the use of the left ITA as a graft to the left anterior descending artery. 4 Furthermore, the long-term patency rates of these grafts at 10 years in contemporary series is substantially lower for venous grafts $(\sim 50 \%)$ than for arterial grafts $(\sim 85 \%){ }^{6}$ Many observational studies show improved patency and are strongly suggestive of a similar survival benefit with the use of additional arterial grafts rather than saphenous vein grafts. Conclusive evidence from a randomized clinical trial for this effect, however, is missing. Most recently, the 10-year data of the Arterial Revascularisation Trial failed to show a survival benefit from the use of both ITAs in their intention-to-treat analysis, an analysis that lost significant power because of a high percentage of treatment crossover. ${ }^{7}$

In this edition of the Journal, Fang and colleagues ${ }^{8}$ report the use of a decellularized xenograft that is coated with an antithrombotic polysaccharide. In their short-term results, they did not see any evidence of thrombosis or degradation of these grafts. Similar results and feasibility studies in animal experiments have been reported previously. 9,10 Such grafts may provide a scalable solution for patients with investigators.

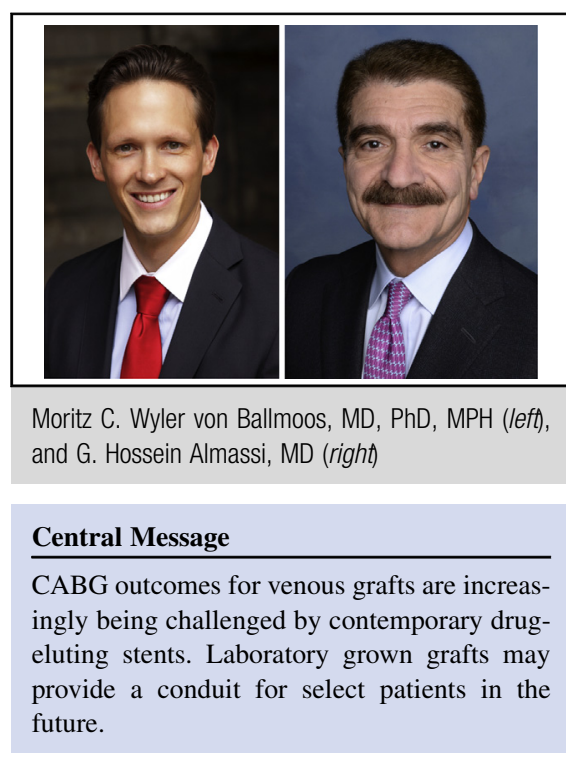

See Article page 461 .

limited options, especially those requiring repeat $\mathrm{CABG}$ after bilateral ITA grafting, and for patients with comorbidities that would prevent harvesting of bilateral ITAs. With an aging population and better medical management, reoperative CABG may also become more frequent. The major limitation of this study remains the short period during which the grafts were examined. The study time frame does not compare by any means with the long-term data that we have for autologous graft options. Presence of a low-grade immune reaction, much like cardiac allograft vasculopathy, and chronic mechanical strain, in the absence of robust media and adventitia, potentially could shorten the lifespan of such a hybrid graft significantly. Although efforts toward an "off the shelf" solution for $\mathrm{CABG}$ grafts are laudable, it is also clear that much more work is needed to determine the long-term durability of such grafts. In the interim, promoting the use of more arterial grafts in preference to venous grafts appears to be the only sensible choice to reduce the risk of repeat revascularization, reduce the risk of major adverse cardiac events, and possibly improve survival. With an ongoing need for surgical revascularization in an increasingly complex patient population, we look forward to more long-term studies on hybrid grafts from this group and other 


\section{References}

1. Head SJ, Börgermann J, Osnabrugge RL, Kieser TM, Falk V, Taggart DP, et al. Coronary artery bypass grafting: part 2-optimizing outcomes and future prospects. Eur Heart J. 2013;34:2873-86.

2. Head SJ, Kieser TM, Falk V, Huysmans HA, Kappetein AP. Coronary artery bypass grafting: part 1-the evolution over the first 50 years. Eur Heart J. 2013;34:2862-72.

3. Organisation for Economic Co-operation and Development. Health at a Glance 2017. Available at: http://www.oecd.org/health/health-systems/health-at-a-glance19991312.htm.

4. Loop FD, Lytle BW, Cosgrove DM, Stewart RW, Goormastic M, Williams GW, et al. Influence of the internal-mammary-artery graft on 10-year survival and other cardiac events. N Engl J Med. 1986;314:1-6.

5. Cameron A, Davis KB, Green G, Schaff HV. Coronary bypass surgery with internal-thoracic-artery grafts-effects on survival over a 15 -year period. $N$ Engl J Med. 1996;334:216-9.

6. Goldman S, Zadina K, Moritz T, Ovitt T, Sethi G, Copeland JG, et al; VA Cooperative Study Group \#207/297/364. Long-term patency of saphenous vein and left internal mammary artery grafts after coronary artery bypass surgery: results from a Department of Veterans Affairs cooperative study. J Am Coll Cardiol. 2004;44:2149-56.

7. Taggart DP, Benedetto U, Gerry S, Altman DG, Gray AM, Lees B, et al; Arterial Revascularization Trial Investigators. Bilateral versus single internal-thoracicartery grafts at 10 years. $N$ Engl J Med. 2019;380:437-46.

8. Fang Q, Gu T, Fan J, Zhang Y, Wang Y, Zhao Y, et al. Evaluation of a hybrid small caliber vascular graft in a rabbit model. J Thorac Cardiovasc Surg. 2020;159: 461-73.

9. Wu W, Allen RA, Wang Y. Fast-degrading elastomer enables rapid remodeling of a cell- free synthetic graft into a neoartery. Nat Med. 2012;18: 1148-53.

10. Dahl SL, Kypson AP, Lawson JH, Blum JL, Strader JT, Li Y, et al. Readily available tissue-engineered vascular grafts. Sci Transl Med. 2011;3:68ra69. 